\title{
Membangun Kesadaran Terhadap Lingkungan Melalui Pembelajaran \\ Bahasa Indonesia
}

\author{
Wira Santika/1801695 \\ wirasantika03022000@gmail.com
}

Tidak hanya di Indonesia, tetapi di seluruh dunia mengalami kerusakan lingkungan. Menurut Mitsuki dan Lai (dalam Ramadhan et al, 2019) di seluruh dunia, setiap orang menghadapi masalah lingkungan yang serius, seperti pemanasan global, hujan, asam, perusakan lapisan ozon, pencemaran lingkungan, kerusakan alam, dan hilangnya keanekaragaman hayati yang dapat mengancam kehidupan generasi sekarang, terutama generasi mendatang. Masalah lingkungan disebabkan oleh aktivitas manusia yang ceroboh terhadap alam guna memenuhi dan meningkatkan kualitas hidup mereka (Huang dan Kawata, dalam Ramadhan et al, 2019). Aspek yang lebih mengancam adalah ketidaksadaran pengaruh manusia bagi lingkungan mereka. Masyarakat saat ini dihadapkan dengan masalah lingkungan yang menimbulkan terjadinya bencana alam.

Salah satu masalah lingkungan yang dihadapi Indonesia yaitu masalah sampah. Melihat kondisi lingkungan saat Pandemi Covid-19 sekarang ini, di Indonesia bertambahnya jumlah sampah rumah tangga dan sampah medis, serta pencemaran lingkungan dari penyemprotan disinfektar. Sampah medis yang meningkat drastis berupa plastik medis, sarung tangan, masker yang sekali pakai, jarum suntik, sampah radioaktif, dan sampah infeksius yang dapat menularkan penyakit berbahaya. Masyarakat Indonesia banyak yang belum sadar tentang pentingnya membuang sampah pada tempatnya. Pada saat Covid-19 ini banyak ditemukan sampah-sampah seperti sarung tangan lateks dan masker yang memenuhi pantai-pantai, sungai, dan selokan, bahkan penyelam juga banyak menemukan sampah medis seperti, masker dan APD di dasar laut.

Lai (dalam Ramadhan et al, 2019) mengatakan bahwa masalah lingkungan secara inheren tidak dapat dipisahkan dari kesadaran lingkungan, nilai-nilai, dan sikap manusia. Ini mendorong negara untuk mulai menilai pendidikan lingkungan. Pendidikan lingkungan hidup adalah suatu proses untuk membangun populasi manusia di dunia yang sadar dan peduli terhadap lingkungan total (keseluruhan) dan segala masalah yang berkaitan dengannya, dan masyarakat yang memiliki pengetahuan, keterampilan, sikap 
dan tingkah laku, motivasi serta komitmen untuk bekerja sama, baik secara individu maupun secara koektif, untuk dapat memecahkan berbagai masalah lingkungan saat ini, dan mencegah timbulnnya masalah baru (UNESCO, Deklarasi Tbilisi, 1977).

Pendidikan lingkungan penting diberikan kepada siswa sedini mungkin agar siswa terbiasa untuk selalu menjaga lingkungan sekitarnya. Pendidikan lingkungan yang pertama kali diperoleh oleh siswa adalah daam lingkungan keluarga inti, hal ini dikarenakan sebelum siswa belajar di sekolah, siswa belajar dari orang tua mengenai pentingnya menjaga lingkungan hidup. Selain dari keluarga inti, masyarakat sekitar juga dapat memberikan pelajaran mengenai peduli terhadap lingkungan masyarakat. Barulah pada usia sekolah, guru-guru sekolah melanjutkan pembelajaran tentang lingkungan secara lebih lengkap. Akan tetapi, untuk menggabungkan pendidikan lingkungan ke dalam pembelajaran bahasa tidaklah mudah. Guru harus memiliki pengetahuan yang diperlukan dan kesiapan lingkungan agar kegiatan di dalam kelas menjadi efektif (Ramadhan et al, 2019).

Jika dihubungkan dengan bahasa Indonesia, maka topik tentang lingkungan bisa dimasukkan ke dalam pembelajaran bahasa Indonesia berupa teks, hal ini dikarenakan topik tersebut juga dapat digabungkan ke dalam mata pelajaran lainnya (Ramadhan et al, 2019). Menurut Rivers (dalam Ramadhan et al, 2019) mengatakan sebagai guru bahasa, kami adalah guru yang paling beruntung, semua mata pelajaran adalah milik kami. Apapun yang ingin dikomunikasikan oleh siswa kami, apapun yang ingin mereka baca merupakan materi pelajaran kami. Menurut Hauchild, Poltavthenko dan Stoller (dalam Ramadhan et al, 2019) guru bahasa berada dalam posisi unik untuk mempromosikan kesadaran lingkungan.

Data pada esai ini berasal dari penyebaran angket melalui watsapp yang berisi sepuluh pernyataan dengan opsi sangat setuju, setuju, kurang setuju, dan tidak setuju dengan topik Pentingnya Materi Lingkungan kepada 40 responden. Hasil penelitiannya sebagai berikut:

Pertama, lingkungan dapat dijadikan sumber pembelajaran bahasa Indonesia bertujuan sebagai proses komunikasi atau interaksi antarmasyarakat. 50\% menyatakan sangat setuju dan $50 \%$ menyatakan setuju. 
Kedua, dengan adanya lingkungan sebagai media pembelajaran siswa lebih akrab dengan lingkungan sehingga menumbuhkan rasa cinta akan lingkungan. 50\% menyatakan sangat setuju dan 50\% menyatakan setuju.

Ketiga, semua lingkungan yang ada di sekitar dapat dijadikan sebagai media pembelajaran bahasa Indonesia. 17,5\% menyatakan sangat setuju, 72,5\% setuju, dan $10 \%$ kurang setuju.

Keempat, memberikan materi lingkungan dalam pembelajaran bahasa Indonesia merupakan salah satu upaya membangun kecerdasan ekologis. 42,5 menyatakan sangat setuju, 52,5\% setuju, dan 5\% kurang setuju.

Kelima, penggunaan bahasa Indonesia di lingkungan sekolah lebih efektif digunakan daripada bahasa daerah. 35\% menyatakan sangat setuju, 57,5\% setuju, dan 7,5\% kurang setuju.

Keenam, materi lingkungan dalam pembelajaran bahasa Indonesia di sekolah merupakan alternatif untuk menumbuhkan minat dan semangat peserta didik. 32,5\% menyatakan sangat setuju, $62,5 \%$ setuju, dan 5\% kurang setuju.

Ketujuh, upaya pelestarian lingkungan melalui teks-teks bacaan dalam pembelajaran bahasa Indonesia memberikan gambaran tingginya pengetahuan siswa terhadap alam. $30 \%$ menyatakan sangat setuju dan $70 \%$ menyatakan setuju.

Kedelapan, materi lingkungan memudahkan siswa dalam memahami pembelajaran bahasa Indonesia dengan baik. 32,5\% menyatakan sangat setuju, 55\% setuju, dan 12,5\% kurang setuju.

Kesembilan, materi lingkungan sangat penting untuk diterapkan dalam pembelajaran bahasa Indonesia. 45\% menyatakan sangat setuju, 50\% setuju, dan 5\% kurang setuju. Kesepuluh, lingkungan dapat menjadi media pembelajaran yang paling disukai. 32,5\% menyatakan sangat setuju, $62,5 \%$ setuju, dan 5\% kurang setuju.

Dari hasil penelitian melalui angket yang telah penulis lakukan dapat disimpulkan bahwa banyak siswa, mahasiswa, serta guru yang setuju bahkan sangat setuju untuk menghubungkan materi lingkungan dengan pembelajaran bahasa Indonesia. Dengan pembelajaran bahasa Indonesia guru bisa memperkenalkan dan membangun kesadaran siswa terhadap lingkungan, sehingga dapat meningkatkan rasa peduli siswa terhadap lingkungan. 


\section{Daftar Pustaka}

Akman O and Alagoz B. 2017. A study on environmental-oriented knowledge, attitude and behavior level of teacher candidates Journal of Education and Practice 8(1) $229-45$

Bergman, B. G. (2016). Assessing impacts of locally designed environmental education projects on students' environmental attitudes, awareness, and intention to act Environmental Education Research 22(4) 480-503.

Buldur, A . and Omeroglu, E. (2018). An examination of the relationship between preschool children's and their teacher' attitute and awareness towards the environment Journal of Education ang Learning 7(2) 221-9.

Erdogan M. 2015. The effect of summer environmental education program (SEEP) on elementary school students' environmental literacy International J. Sci. Env. Ed. 10(2) 165-181.

Hauchild S, Poltavthenko E and Stoller F L. (2012). Going green: Menging environmental education and language instruction English Teaching Forum 213.

Kollmuss A and Agyeman J. (2002). Mind the gap: Why do people act enviconmentally and what are the barriers to pro-environmental behavior Environmental Education Research 239-60.

Lai, C.S., Sukma, E., \& Indriyani, V. (2019). Enviromental learning outcomes in taipei International Journal of Research in Education and Science 4(1) 252-61.

Mitsuki I. (2017) Beyond the limitations of environmental education in Japan Educational Studies in Japan: International Yearbook 3-14.

Napoli M. (2011) Going green: Empowering readers to change the environment Kappa Delta Pi Record 4776-9.

Nazarenko, A.V. and Kolesnik, A.I. (2018). Raising environmental awareness of future teachers International Journal of Instruction 11(3) 63-76.

Nkwetisma C M. (2011) EFL/ESL and environmental education: towards an eco applied linguistic awareness in Cameroon World Journal of Education 1 110-18.

Ramadhan, S., Sukma, E., \& Indriyani, V. (2019). Environmental education and disaster mitigation through language learning. IOP Conference Series: Earth and Environmental Science, 314. 
